\title{
ATTITUDES AND PERCEPTIONS OF SOUTH AFRICAN MILITARY ACADEMY STUDENTS TOWARDS INFORMATION AND COMMUNICATION TECHNOLOGY AND COMPUTERS
}

\author{
Maj William Moswetsi ${ }^{1}$, Lt Col Jaco Renken (Computer \\ Information Systems) and Dr Ariane Neethling (Statistics), \\ Faculty of Military Science, Stellenbosch University
}

\begin{abstract}
The proliferation of computer technology in both our personal and professional lives, and particularly during the last decade, has created an environment in which there are varying perceptions of, and ideas about, the value of Information and Communication Technology (ICT) and computers. In order to benefit from this, especially in a defence environment, a realistic perception about the worth of computers needs to be established. This paper presents the findings of a survey that was conducted to determine attitudes towards ICT/computers among students of the SA Military Academy. Two hypotheses were tested: (1) There are significant differences in attitude towards computers between students of different Arms of the Service; gender; academic year groups; ranks; those having previous experience with computers; and those owning a personal computer (PC); (2) There are significant differences in perception towards the value of ICT/computers between students within these groupings. In brief, the study concluded that there was a significant difference between experienced and less experienced students in the perceived value of ICT/computers in the work place and their personal lives.
\end{abstract}

\section{Introduction}

The profoundness of the impact of Information and Communication Technology (ICT) and computers on society is undisputed. A consistent stream of

\footnotetext{
${ }^{1}$ Maj Moswetsi is an officer of the Botswana Defence Force. The article was initially handed in as a graduate research paper in the School for Geospatial Studies and Information Systems of the Faculty of Military Science.
} 
technological advances resulted in numerous inventions that have not only furnished humanity with high-tech gadgets, but changed the way in which things are done. These changes are particularly evident in the realms of business, recreation, health care, social work, and also warfare.

History is splattered with accounts of how technology has impacted and changed the face of warfare. World War II was ended with an astonishing technological achievement: the nuclear bomb. The successful deployment of these weapons of mass destruction by the US was soon followed by the detonation of the Soviet Union's first hydrogen bomb, preceded by a nuclear bomb of their own. The dangerous arms race that characterised the Cold War had commenced. This struggle for power and military superiority lasted for more than four decades and was characterised by remarkable technological achievements. ${ }^{1}$

Perry $^{2}$ pointed out: "Today the threat of terrorism and the threat of proliferation are the greatest to our security. It seems likely that the American military will remain the dominant military force in the world for the foreseeable future, but this can have unintended consequences. It can lead to a nightmare scenario where a terror group may attack us with weapons of mass destruction." He went on to emphasize the critical importance of advanced information technology in countering these new threats. And this responsibility, primarily, lies within the domain of the armed forces.

Axberg $^{3}$ considered the importance of technology in strategic military operations and aptly pointed out that technology, in itself, cannot solve any military problems. He argues that only the officer's ability to apply his technological knowledge can play a decisive role in military operations. These considerations were the motivation for the introduction of mandatory courses in military technology for all first degree programmes at the Swedish National Defence College and Royal Canadian Military College amongst other military academies, colleges and universities worldwide. The SA Military Academy academic programme content reflects a move in the same direction.

The proliferation of computer technology throughout the South African National Defence Force (SANDF), during the last decade, has created an environment in which there are varying perceptions about the value of ICT/computers. Perception refers to a person's awareness or appreciation of something. The term Information and Communication Technology is used instead of Information Technology (IT) to recognise the convergence of traditional 
information technologies and telecommunications, which were once seen as distinct areas. To benefit from this widespread use of ICT/computers, a realistic perception about the worth of ICT/computers needs to be established amongst officer-students at the SA Military Academy.

A vast variation in attitudes towards ICT/computers could hamper the effectiveness of the armed services. It may also be said that, due to the multiplicity of micro-processor-embedded weapon systems in all Arms of the Service (AoS), a large knowledge base about computer systems and the value of ICT is not only desirable, but of paramount importance. Security issues relating to computer systems, for example, may have a significant impact on the use of these weapon systems.

The aim of this paper is, firstly, to establish whether there are any differences in the attitudes of undergraduate students towards ICT/computers. Secondly, it is necessary to determine how the different AoS; differentiation in military seniority; gender; previous computer training; academic year groups and those who own a PC and those who do not, regard the value of ICT/computers. To accomplish the above aim, the following questions need to be addressed:

- Is there a difference in the perceptions of those with previous computer training and those with no computer training towards ICT/computers?

- Is there a difference in the perception between male and female members towards ICT/computers?

- Is there a difference in perception of ICT/computers between those who own a computer and those who do not own a computer?

- Is there a difference in perception of ICT/computers among members of different AoS?

- Is there a difference in perception of ICT/computers among different year groups?

- Is there a difference in perception of ICT/computers among ranks?

- Is there a difference in perception of the value of ICT/computers in the strategic use of ICT/computers amongst these groups?

In view of the above, this paper will start with a brief literature review on related research that has been done on attitudes towards ICT/computers. The second part will address the research questions stated above. Finally, the results of this study will be presented and discussed. 


\section{Literature review}

Individual attitudes towards computers are key to understanding users' acceptance of, and satisfaction with, computer-based information systems. As such, these attitudes have been of interest to researchers in a variety of disciples and for some time now. Numerous studies have been conducted on attitudes towards computers in a variety of settings and numerous instruments have been developed to measure this construct.

Since Lee's studies of social attitudes towards computers, there have been several more attempts to study these attitudes. ${ }^{4}$ Lee undertook a study to examine popular beliefs and attitudes about computers. ${ }^{5}$ This study led to the construction of a questionnaire with 20 statements designed to tap major themes, beliefs and ideas about computers. To reveal the structure of attitudes and beliefs about computers as measured by reactions to the 20 statements, a correlation matrix was computed and a factor analysis based on the Varimax rotation procedure was conducted. Two factors emerged: the positive and the negative factor. ${ }^{6}$ Other studies were subsequently conducted to expand the two dimensions used to assess the attitude towards computers.

Rose and Weil conducted a nationwide study in Southern California to clarify the reactions that teachers have to information and communication technology. The study was designed to assess technophobia in the public school system in a large urban area. The study concluded that, although teachers have increased computer availability in their classrooms, they are not integrating computers into the curricula. $^{7}$

Several researchers have reported on the use and utilisation of computers. ${ }^{8}$ Al-Khaldi \& Al-Jabri, for instance, examined how utilisation was affected by some demographic and non-attitudinal variables in a Saudi Arabian university. Their findings indicated that the overall attitudes did affect computer utilisation. The study also showed that other variables appeared to have a strong influence on computer utilisation, namely the extent of computer experience, the degree of access to computers and the number of computer-related courses taken. ${ }^{9}$

In 2000, Young conducted a study in which a survey of student attitudes to computers was developed and used to explore differences in attitude towards computers among middle and high school students. ${ }^{10}$ The study indicated that gender differences in attitude resulted from a greater confidence among males about 
information technology and the perception amongst females of computers as a male domain and hence a rejection of computers by them. Research, generally, supports the opinion that females have less overall experience with computers and are more likely than males to have negative attitudes towards computers. ${ }^{11}$ These authors also indicated that males have more experience with computers because of the continuing dominance of male ownership of computers. Other researchers have also concluded that ownership of a computer increases positive attitudes towards computers in general. ${ }^{12}$ This focus on computer attitudes is supported by the fact that students' attitudes towards computers can be related to computer use and ultimately the benefits they can derive from computer use.

Moving from the international to the local context, Clarke and Finnie conducted a study in 1998 on first-year students at two South African universities towards computers, based on prior experience with computers, their gender and their first language. ${ }^{13}$ The results indicated that there was no significant difference between males and females. A prior study by Finnie had indicated that there were differences in that females had a less positive view of computers. Females were shown to have greater fear of computers in society and less appreciation of computers in general. ${ }^{14}$

In 2003, Smith and Oosthuizen examined the attitudes of entry-level university students towards computers. ${ }^{15}$ The study was conducted at the University of South Africa and the University of the North (currently known as the University of Limpopo). These authors used a modified version of Lee's 20-item questionnaire to measure the attitudes in two dimensions. ${ }^{16}$ The first dimension reflects the extent to which computers are seen as a beneficial tool, while the second dimension reflects the extent to which computers are seen as an independent thinking machine. The results indicated that the attitudes towards computers, as a beneficial tool, have become more positive and concerns about an 'awesome thinking machine' have declined. ${ }^{17}$

Research on the value of ICT/computers in the armed forces has not been extensive. Renken conducted a study at the SA Military Academy on correcting the perceptions of undergraduate students at the Academy regarding the success that ICT has achieved as a strategic corporate resource. ${ }^{18}$ The result indicated that the majority of students were confident in using ICT/computers, and the success that ICT has achieved as strategic corporate resource is the key to competitiveness, organisational success and improved productivity. This over-optimism about ICT 
has been identified as a possible cause of concern and suggestions were made to align their perceptions with reality.

However, the use of ICT/computers has been widespread in the SANDF and an assessment of perceptions seems both interesting and desirable. Against this background, the focus in the following section will be on the attitudes of students at the SA Military Academy towards ICT/computers.

\section{Methodology}

The methodology used for this survey was a modified version of Lee's instrument, as adopted by Smith and Oosthuizen. The first part of the questionnaire wa aimed at identifying differences in gender, prior experience with computers, rank, arm of service, academic year group, as well as computer ownership. The second part of the questionnaire consisted of 20 questions aimed at determining the attitudes of the participants towards computers and were adopted from Clarke and Finnie. ${ }^{19}$ The third part of the questionnaire was aimed at ascertaining perceptions of the value of ICT/computers.

\section{Procedure}

A pilot study was conducted to evaluate the questionnaire and to ensure that participants would understand the questions. Ambiguities that emanated were removed in order to produce a reliable research instrument.

The questionnaire was administered to a selected sample of students at the Military Academy, representing all AoS using stratified sampling. A factor analysis based on principal components was done by using the SPSS package to group variables in a meaningful way for obtaining overall perceptions. Thereafter the independent T-test and analysis of variance (ANOVA) were applied to establish any significant differences in attitude towards, and perceptions of, the value of ICT/computers.

\section{Sample}

The sample consisted of 90 undergraduate students of the Military Academy chosen from an entire population of 301 students. The sample was stratified according to AoS and academic year group. 
55

Table 1 Demographic profile of respondents

\begin{tabular}{|c|c|c|c|c|c|}
\hline \multicolumn{5}{|c|}{ SERVICE } & \multirow[b]{2}{*}{ Total } \\
\hline YEAR GROUP & Army & Navy & Air Force & Other & \\
\hline 1 & $26(31.7 \%)$ & $7(8.5 \%)$ & $12(14.6 \%)$ & $4(4.9 \%)$ & $49(59.8 \%)$ \\
\hline 2 & $13(15.9 \%)$ & $2(2.4 \%)$ & $1(1.2 \%)$ & $1(1.2 \%)$ & $17(20.7 \%)$ \\
\hline 3 & $11(13.4 \%)$ & $2(2.4 \%)$ & $2(2.4 \%)$ & $1(1.2 \%)$ & $16(19.5 \%)$ \\
\hline Total & $50(61.0 \%)$ & $11(13.4 \%)$ & $15(18.3 \%)$ & $6(7.3 \%)$ & $82(100.0 \%)$ \\
\hline
\end{tabular}

Eighty-two students, comprising first-, second- and third-year participants responded to the questionnaire. The sample consisted of both female and male students and was a reasonable representation of all AoS. Table 1 above indicates the demographic profiles of respondents. A total of 65 (79.3\%) males and 17 (20.7\%) females responded to the questionnaire.

\section{Attitude towards ICT/computers}

Lee's instrument was used to examine the attitudes of undergraduates at the Military Academy towards ICT/computers. The survey was conducted towards the end of the second semester of the 2004 academic year. This may have influenced the attitudes of participants, since all the participants had done a basic computer course during that period. The instrument contained twenty attitude questions rated on a 7-point Likert scale (1=Disagree Strongly, 2=Disagree, $3=$ Disagree Slightly, 4=Neutral, 5=Agree Slightly, 6=Agree, $7=$ Agree Strongly) and six ICT/computer value questions rated on a 5-point Likert scale (1=Disagree Strongly, 2=Disagree, 3=Agree Moderately, 4=Agree, 5=Agree Strongly).

\section{Factor extraction}

Factor analysis is a statistical technique that can be used to find a way of condensing the information contained in a number of original variables into a smaller set of factors with a minimum loss of information.

Seven factors, accounting for $65.9 \%$ of the variance, were identified with factor analysis for the 20 questions measuring the attitudes of the participants towards computers. The factors can be described as follows: 
- $\quad$ Factor 1: This factor is labelled 'awesome thinking machine' following Clarke and Finnie ${ }^{20}$ as cited by Smith and Oosthuizen. ${ }^{21}$ It accounted for $11.92 \%$ of the variance. The variables include "something strange, amazing and smarter".

- Factor 2: This factor is labelled 'beneficial tool of man' following Lee ${ }^{22}$, and loads high on the variable relating to positive impacts of the technology and benefits to the economy. These factors include "economic benefit to the development of the country", "brings a better way of life", "essential and efficient operation of a large organisation" and "speeds up scientific process".

- Factor 3: From Smith and Oosthuizen this factor is labelled 'realisation of computer power'. ${ }^{23}$ The factor includes "people will be replaced by computer", "no limit to what they do", "works at lightning speed" and "extremely accurate and exact".

- Factor 4: This factor, labelled 'danger of computer power', also includes the variables "can be used for evil purpose", "serious mistakes can be made by using computer" and "contribute to unemployment".

- $\quad$ Factor 5: This factor is labelled as 'fear of computer power' from Lee and includes the variables "can think like humans", "free people to do more imaginative work" and "may be controlling our lives in future".

- Factor 6: Only one variable is contained in this factor: "society is going too far in the use of computers". Smith \& Oosthuizen labelled this factor as the 'negative sentiments towards computers'.

- Factor 7: The variables included in this factor are "computers intimidate" and "better decisions can be made by using computers". This factor is labelled as 'computer intimidation'.

In the previous studies four and six factors were tested, while in this study seven factors were used.

For each respondent, an overall value was calculated for each factor by adding the respondent's values of the corresponding variables in that factor. A lower value would refer to an overall 'disagree' opinion, while a higher value would refer to an 'agree' opinion for that factor. For each factor a mean value was calculated and further analysed.

\section{Attitude results}

The above-mentioned factors were examined to establish whether there are any differences in attitudes towards ICT/computers. An independent T-test was 
done for comparing two groups and one-way analysis of variance (ANOVA) for more than two groups. A 5\% level of significance was used. Therefore, a p-value less than 0.05 indicates a significant difference. Fisher's least significant difference method was used to identify multiple comparisons between the different groups.

\section{Gender differences}

The results indicated that there is no significant difference in perceptions towards ICT/computers between males and females (see Figure 1). Much has been said in the literature studies about the attitudes of females to computers relative to those of their male counterparts. ${ }^{24}$ There have been conflicting results. In this study no significant difference in attitudes was observed between males and females.

\section{Figure 1 Mean values of males and females for the different factors}

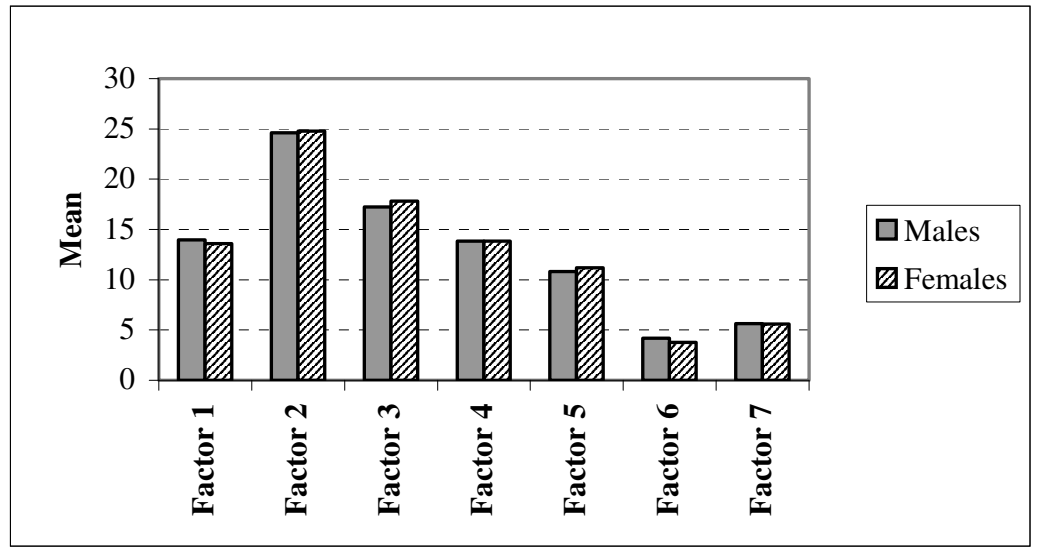

\section{Computer ownership}

In their article Al-Jabri and Al-Khaldi, Mitra and Steffensmeier showed that beyond just having access to computers, ownership of a computer increases students' positive attitude towards computers. ${ }^{25}$ In this study there was no difference in attitude between those who own a computer and those who do not own a computer.

\section{Prior computer training}

Smith and Oosthuizen have shown that there was a significant difference between those with and without prior computer training regarding "awesome thinking machine" (factor 1), "fear of computer power" (factor 4) and "negative sentiments to computer power" (factor 5). ${ }^{26}$ For the students at the SA Military 


\section{8}

Academy, no differences were found between those with and without prior computer training. The reason for this might be attributed to the fact that the survey was conducted towards the end of the academic year, after they had all completed a basic training course in computers.

\section{Arms of the Service}

The sample was a reasonable representation of all AoS and no significant difference was detected between the AoS. It may be said that one would expect to find differences between the army and other AoS, as the other services are much more technologically-orientated. In this study no significant differences were found between the AoS.

\section{Academic year groups}

A significant difference was observed between academic year groups for the component of fear of computer power (factor 5), as shown in Table 2 below. The first-year students are slightly more sceptical about computer power than senior students.

Table 2

Descriptive statistics and comparison of attitude perception between academic year groups

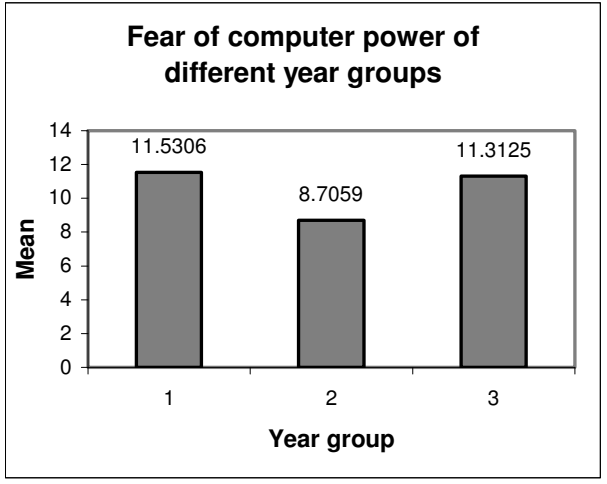

\begin{tabular}{|c|c|}
\hline $\begin{array}{c}\text { Overall } \\
\text { p-value }\end{array}$ & \multicolumn{1}{c|}{$\begin{array}{c}\text { Multiple } \\
\text { Comparison }\end{array}$} \\
\hline 0.040 & 1 vs $2: \mathrm{p}=0.013^{*}$ \\
& 1 vs 3: $\mathrm{p}=0.848$ \\
& 2 vs 3: $\mathrm{p}=0.061$ \\
\hline
\end{tabular}

$1=$ First years,

$2=$ Second years,

$3=$ Third years

* Significant difference

The results indicate that there is an overall significant difference between academic year groups $(\mathrm{p}=0.040)$. The mean value of first-years differs significantly from that of second years, indicating that the first-years are still afraid of computer power. No significant difference was indicated between the second- and third-years. 
Rank/military seniority

The sample consisted of varying military ranks ranging from Candidate Officers and Midshipmen to Captains. A significant difference was detected on the component of danger of computer power (factor 4) between ranks, as can be seen in Table 3 below. The junior officers are slightly more afraid of computer power.

The results in Table 3 indicate that there is a significant difference between ranks $(p=0.023)$. The mean values for Candidate Officers, Midshipmen and Lieutenants are greater than those for Captains, indicating that these lower-rank groups still regard computer power as dangerous. Although no significant difference was found between $2^{\text {nd }}$ Lieutenants and Captains, the former group seems to agree more that computer power is 'dangerous'.

Table 3

Descriptive statistics and comparison of attitude perception between ranks

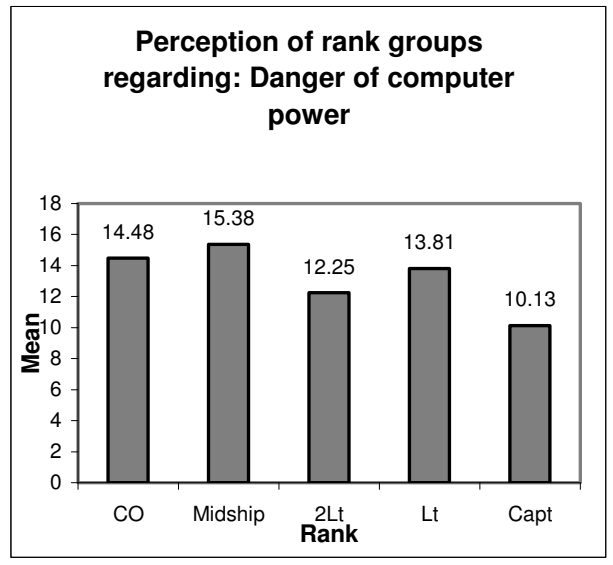

\begin{tabular}{|c|c|}
\hline $\begin{array}{c}\text { Overall } \\
\text { p-value }\end{array}$ & $\begin{array}{c}\text { Multiple } \\
\text { Comparison }\end{array}$ \\
\hline 0.023 & 1 vs 5: $p=0.002^{*}$ \\
& 2 vs 5: $p=0.004^{*}$ \\
& 3 vs 5: $p=0.336$ \\
& 4 vs 5: $p=0.016^{*}$ \\
\hline
\end{tabular}

$1=$ Candidate Officers

$2=$ Midshipmen

$3=2^{\text {nd }}$ Lieutenant

$4=$ Lieutenant

$5=$ Captain

* Significant difference

\section{Value of ICT/computers}

Previous research has shown that the majority of students are confident that ICT/computers are the key to competitiveness, organisational success and productivity. ${ }^{27}$ It has also been shown that computer utilisation is dependent on computer experience, number of computer courses attended and access to computers. ${ }^{28}$

In line with previous research findings, the results of this study have shown that there is no statistical proof to suggest that there is any difference in 
attitudes towards the value of ICT in the armed forces between males and females; those who attended a computer course before and those who did not; those who own a PC and those who do not. However, some differences were found between the AoS, academic year groups and military seniority.

\section{Difference between Arms of the Service}

Table 4 below shows that there is a significant difference between the AoS in the way that they perceive the value of ICT/computers with respect to the way that computer technology has changed the art of war $(p=0.039)$

Table 4

Descriptive statistics and comparison of perceived value of ICT/computers between the AoS

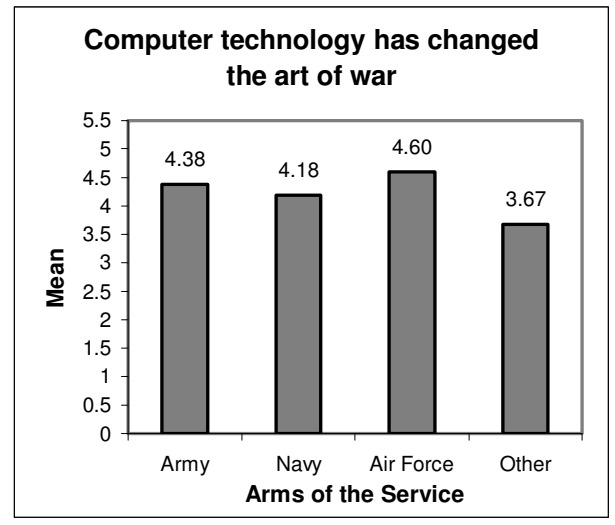

\begin{tabular}{|c|c|}
\hline $\begin{array}{l}\text { Overall } \\
\text { p-value }\end{array}$ & $\begin{array}{c}\text { Multiple } \\
\text { Comparison }\end{array}$ \\
\hline 0.039 & $\begin{array}{l}1 \text { vs } 4: p=0.018^{*} \\
2 \text { vs } 4: p=0.141 \\
3 \text { vs } 4: p=0.006^{*}\end{array}$ \\
\hline \multicolumn{2}{|c|}{$\begin{array}{l}1=\text { Army } \\
2=\text { Navy } \\
3=\text { Air Force } \\
4=\text { Other }\end{array}$} \\
\hline * Signific & t difference \\
\hline
\end{tabular}

While keeping in mind the small numbers of students in the SAMHS and SAMIS, the mean value for Other (SAMHS, SAMIS) is lower than for the Army, Air Force and Navy, indicating that the latter services believe that computer technology has changed the art of war.

\section{Difference in academic year group}

Table 5 indicates that there is a significant difference between academic year groups in the way that they perceive the value of ICT/computers and on how computer technology can be used to monitor the battlefield (0.023).

The mean values for second-years and third-years are greater than those for the first-years, indicating that first-years are more afraid to use computers in centralised monitoring and control of the battlefield. 
Table 5

Descriptive statistics and comparison of perceived value of ICT/computers between academic year groups

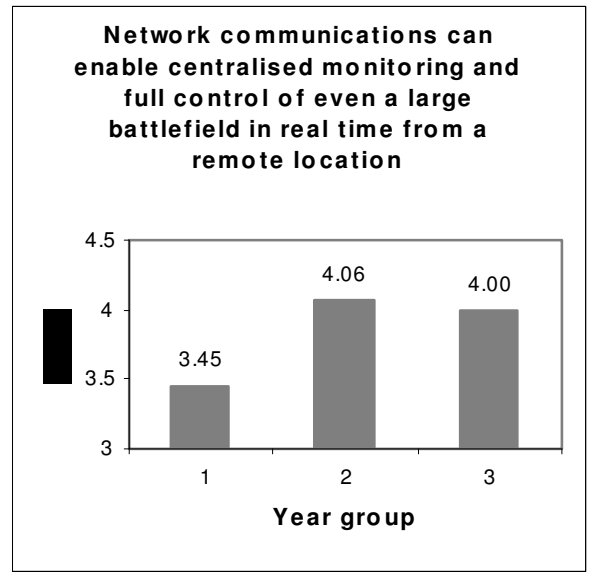

\begin{tabular}{|c|c|}
\hline $\begin{array}{c}\text { Overall } \\
\text { p-value }\end{array}$ & $\begin{array}{c}\text { Multiple } \\
\text { Comparison }\end{array}$ \\
\hline 0.023 & 1 vs 2: $\mathrm{p}=0.020^{*}$ \\
& 1 vs 3: $\mathrm{p}=0.044^{*}$ \\
& 2 vs 3: $\mathrm{p}=0.856$ \\
\hline
\end{tabular}

$1=$ First years,

$2=$ Second years,

$3=$ Third years

* Significant difference

\section{Difference between ranks}

Table 6 indicates that there is a significant difference between ranks in the way computer technology can be used to monitor and control the battlefield ( $\mathrm{p}=$ 0.016). The mean value for Lieutenants is greater than for all other ranks, indicating varying perceptions about using computers on the battlefield.

Table 6

Descriptive statistics and comparison of perceived value of ICT/computers between ranks

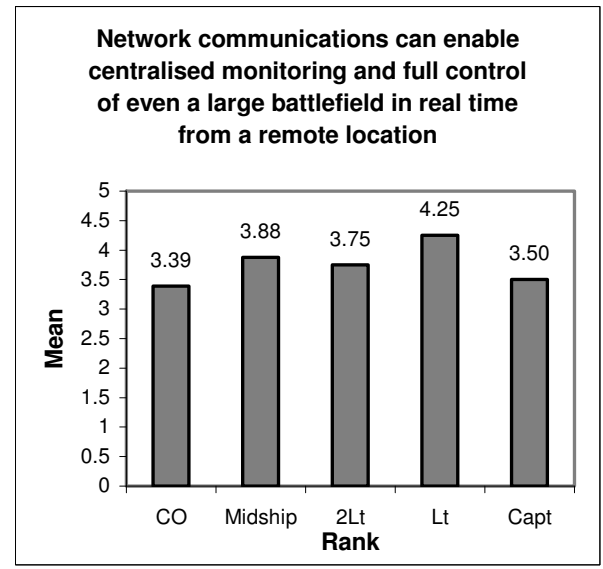

\begin{tabular}{|c|c|}
\hline $\begin{array}{c}\text { Overall } \\
\text { p-value }\end{array}$ & $\begin{array}{c}\text { Multiple } \\
\text { Comparison }\end{array}$ \\
\hline 0.016 & 1 vs 4: $\mathrm{p}=0.001^{*}$ \\
& 2 vs 4: $\mathrm{p}=0.321$ \\
& 3 vs 4: $\mathrm{p}=0.312$ \\
& 5 vs 4: $\mathrm{p}=0.049^{*}$ \\
\hline
\end{tabular}

$1=$ Candidate Officers

$2=$ Midshipmen

$3=2^{\text {nd }}$ Lieutenant

$4=$ Lieutenant

5 = Captain

* Significant difference 


\section{Discussion of results}

In this study, the attitudes of students at the SA Military Academy were measured during the second semester of the academic year 2004. During this period all students had the opportunity to take the course "Introduction to Computers".

The research questions concerning the attitudes and perceived value of ICT/computer posed earlier in section 1 have been answered as follows:

- There is no significant difference in attitude between males and females.

- There is no significant difference between owners of PCs and those who do not.

- There is no significant difference in attitude between those who have previously done a computer course and those who did not.

- There is no significant difference in attitude among members of the different AoS.

The reason for this may be attributed to the fact that most students did an introductory course to computers at the Military Academy. However, the following significant differences were found:

- There is a significant difference in attitude between first-year and secondyear students regarding the fear of computer power (factor 5). This could be ascribed to the fact that first-year students with little knowledge of computers still find this kind of technology more intimidating than the (more experienced) second-years.

- There is also a significant difference in attitudes between Captains and most of the other ranks regarding "danger of computer power" (factor 4). This situation could be ascribed to the fact that Captains have been in the army for a longer period and have more experience with computers at their different services, enabling them to realise that computer power is not necessarily a problem.

The second part of the research question was to establish how students perceive the value of ICT during war. The research question has been answered as follows:

- It has been found that there are significant differences in perception between Army, Air Force and Others (SAMHS, SAMIS) of the way that 


\section{3}

ICT/computers have changed the art of war. This may be attributed to the fact that SAMHS are generally not primarily involved in the conduct of war and as such do not realise the value of ICT during war.

- It has also been found that there is a significant difference between the ways that first-year students and senior students perceive the use of ICT by a defence force. This situation could be ascribed to lack of career experience of the first-year students. The data also suggest that only about half the students have their own personal computer or received training in ICT/computers prior to their tour at the Military Academy. This might be a significant factor to be considered if similar surveys would be conducted in developed countries.

- There is a significant difference in perception between Captains, Lieutenants and Candidate Officers of the way that centralised monitoring of the battlefield could be achieved by using ICT/computers. This could be ascribed to the varying levels of battlefield experience.

\section{Limitations and directions for future research}

Most participants did not identify in which academic programme they were enrolled and therefore no attempt was made to establish the difference in perceptions according to academic programmes, which might produce some interesting findings.

An area for possible future research would be to assess the perceptions of the entire officer corps of the SANDF. Furthermore, it would be interesting if this study could be expanded to include members of the SANDF who are noncommissioned officers to compare generational and demographic differences.

\section{Contributions and conclusions}

The contribution of this study could be considered from two perspectives: firstly, from an officer training point of view, and secondly, from an information systems research point of view. This said, it is of particular interest to assess how perceptions of ICT/computers in a military context compare with the situation in a more commonplace, civilian setting. Numerous research initiatives have been conducted and are continuously being refined in order to assess the perceptions of students and how these perceptions can be influenced. But the ability to generalise these results and apply the recommendations to the military environment remains questionable. This study has attempted to shed some light on these issues by using a 
set of key concepts for constructing a contribution to the information systems body of knowledge. ${ }^{29}$ Three key observations will now be discussed.

A degree of non-coherence emerged between the empirical results of this investigation and previous studies that were considered in the literature review. Although not absolutely definitive, the results indicate that suspicion about the direct applicability of similar studies undertaken in a civilian setting is not unfounded. It can therefore be argued that this study confirms the need for more investigation into the uniqueness of the military environment.

The existing literature does not sufficiently incorporate different perspectives and views to better understand the role of ICT/computers in the military environment. The impact of the organisational context on these perceptions might even have been overlooked. This study offers these initial empirical findings in order to encourage further investigations into this theme. This is an important consideration from an information systems perspective, where a fundamental point of departure is that technology cannot be separated from the people and context in which it is used.

The findings also have implications for the training of officers. Rapid advancement in technological developments not only affects the military, but is often led by the defence industries. The case of information technology is no different. These results highlight the importance of influencing the perceptions of officers under training in order to optimise their preparedness for the operational environment. Clausewitz (1976) might have had the impact of technological developments in mind when he contrasted the logic of war as unchanging with the constantly evolving grammar of warfare. ${ }^{30}$ This research emphasises the importance of providing contextualised information systems training to military personnel in a purposeful way.

With the proliferation of computer technology in our homes and work places, it could be justified to suggest that the research is partially consistent with previous research in that most students realise the value of ICT/computers. It is therefore advisable that the scope of the course "Introduction to Computers" at the SA Military Academy also involve some emphasis on the value of ICT - thereby extending a mere focus on computer awareness.

In the information age computer skills are becoming increasingly important and armed forces without these skills are at a disadvantage in terms of 
information warfare. This study raises both hope and concern. The comparison of students' attitudes to ICT/computers in this study with previous studies indicates clearly that with increasing overall computer use gender differences, ownership of computer differences and prior training in computer differences have diminished. However, there is need during officers' formative training for the use of computers to be incorporated with a view to ensuring that candidate officers and Midshipmen are made aware of the importance of ICT/computers during wartime situations.

It has also been found that there is no significant difference in attitudes towards computers in the different groups, for example, male versus female, those with previous computer training and those without previous computer training. There is, therefore, no significant value in directing initiatives to change perceptions according to various groups, but it is necessary rather to focus on designing instructional resources to correct perceptions.

\section{References}

${ }^{1}$ Perry, W.J. Military Technology: An Historical Perspective. Technology in Society. Vol. 26, Issue 2-3, April-August 2004, pp. 235-243.

${ }^{2}$ Ibid.

${ }^{3}$ Axberg, S. Technology Writes the History of War. Framsyn Magazine, Issue 1, JanuaryFebruary 2005.

${ }^{4}$ Lee, R.S. Social Attitudes and the Computer Revolution. Public Opinion Quarterly. Vol. 34, 1970, pp. 53-59.

${ }_{6}^{5}$ Ibid.

${ }^{6}$ Ibid.

${ }^{7}$ Rose, L.D \& Weil, M.M. Computer Availability, Experience and Technophobia among Public School Teachers. Computers in Human Behaviour. Vol. 11, No 1, 1995, pp. 9-31.

${ }_{8}$ Mitra, A. Categories of Computer Use and their Relationships with Attitudes towards Computers. Journal of Research on Computing in Education. Vol. 30, Issue 3, Spring 1998, pp. 281-296.

${ }_{9}$ Al- Khaldi, M.A \& Al-Jabri, I. The Relationship of Attitudes to Computer Utilization: New Evidence from a Developing Nation. Computers and Human Behaviour. Vol. 14, No 1, 1998, pp. 23-42.

${ }_{10}$ Young, B.J. Gender Differences in Student Attitudes towards Computers. Journal of Research on Computing in Education. Vol. 33, Issue 2, Winter 2000, pp. 204-217.

11 Schumacher, P \& Morahan-Martin, J. Gender, Internet and Computer Attitudes and Experiences. Computers in Human Behaviour. Vol. 17, Issue 1, January 2001, pp. 95-110.

${ }^{12}$ Al-Jabri, I \& Al- Khadi, M. Effects of User Characteristics on Computer Attitudes among Undergraduate Business Students. Journal of End-User Computing. Vol. 9, Issue 2, 1997, pp. 16-22.

${ }^{13}$ Clarke, M.C \& Finnie, G.R. Changes in Entry-Level University Students' Attitude towards Computers for 1985-1987. South Africa Computer Journal. Vol. 21, August 1998, pp. 26-32.

${ }^{14}$ Finnie, G.R. Novice Attitude Changes during the First Course in Computing: A Case Study. Questiones Informatice. Vol. 5, Issue 2, October1987, pp. 56-62. 
${ }^{15}$ Smith, E \& Oosthuizen, H.J. An Investigation of the Attitude of Entry-Level University Students towards Computers. Proceedings of the $33^{\text {rd }}$ annual conference of the South African Computer Lecturers Association. July 2003. Manyane, Pilanesberg.

${ }^{16}$ Lee, R.S, op cit.

${ }^{17}$ Smith, E \& Oosthuizen, H.J, op cit.

${ }^{18}$ Renken, J.C. Correcting the Perception of Undergraduate Students about the Success that ICT has achieved as a Strategic Corporate Resource. Proceedings of the $33^{\text {rd }}$ annual conference of the South African Computer Lecturers Association. July 2003. Manyane. Pilanesberg.

${ }^{19}$ Clarke, M.C \& Finnie, G.R, op cit.

${ }^{20} \mathrm{Ibid}$.

${ }^{21}$ Smith, E \& Oosthuizen, H.J, op cit.

${ }^{22}$ Lee, R.S, op cit.

${ }^{23}$ Ibid.

${ }^{24}$ Smith, E \& Oosthuizen, H.J, op cit; Clarke, M.C \& Finnie, G.R, op cit.

${ }^{25}$ Al-Jabri, I \& Al- Khadi, M. Effects of User Characteristics on Computer Attitudes among Undergraduate Business Students. Journal of End-User Computing. Vol. 9, Issue 2, 1997, pp. 16-22; Mitra, A \& Steffernsmeier, T. Changes in Student Attitude and Student Computer Use in a Computer Enriched Environment. Journal of Research on Computing in Education. Vol. 32, Issue 3, Spring 2000, pp. 417-434.

${ }^{26}$ Smith, E \& Oosthuizen, H.J, op cit.

${ }^{27}$ Renken, J.C, op cit.

${ }^{28}$ Al- Khadi, M.A \& Al-Jabri, I.M, op cit.

29 Barrett, M. \& Walsham, G. Making Contributions from Interpretive Case Studies: Examining Processes of Construction and Use, in: Information Systems Research: Relevant Theory and Informed Practice, Proceedings of the IFIP WG 8.2 Conference, July 2004, Manchester, pp. 293-312.

${ }^{30}$ Clausewitz, C. On war, Edited and Translated by Howard, M \& Paret, P. Princeton University Press, Princeton. 1976, p. 605. 